\title{
THE ROLE OF CONTEMPORARY ART IN MONITORING THE PHENOMENON OF ILLEGAL IMMIGRATION
}

\author{
Sahar Muhammad Othman DARGHAM*
}

Department of Painting, Faculty of Fine Arts, Alexandria University, Egypt.

\begin{abstract}
On the monitoring of the phenomenon of illegal immigration and how it began and expanded at the level of several countries, and accordingly the research is divided into two parts: The first part: an information narration about the concept of illegal immigration, its emergence, the concept of informal migration and its problems - international conventions - recent international conferences on migration and migrants - Statistics on the number of illegal immigrants around the world - recent photos of different types of immigrants - and mass migrations. The poor sanitary status of migrants. The second part: an artistic narration of a type of artists who stopped at this phenomenon, and produced various works. The product, where some artists previously issued artworks inspired by events as an artistic repelling wall, may illuminate, or it may shed light or may prevent in the future some danger to humanity, such as accompanying The phenomenon is human trafficking. Artists 'works depended on not separating between art and politics. On the contrary, political matters became a new platform from which the gatherings advocating for human rights and advocacy for environmental protection emerged. Politics was considered a new platform in which artists take a purely artistic documentary, but is influenced by events and opinions surrounding the world in general, and countries in particular. Keywords

Contemporary Art, Monitoring, Phenomenon, Illegal Immigration.
\end{abstract}

\section{Introduction}

The research adopts the humanitarian position of illegal immigrants and not the political position where the weakness of the human being at that time reaches its height and its peak from their psychological state that they have been cut off the reasons for continuing in their place, to their decision to go out into the unknown and the obstacles of crossing and coming into contact with the legislated laws for each of the borders they find in their way - and the loss of their relatives During the long journey for nights and days during the transit - but they remain in transit and travel - they do not feel safe either in their original land from which they left, nor in every land their feet touch from the start of the decision to move - and during the journey they continue to walk and face the difficulties of moving - many of them fall in the face of Crossing a torrential river or barbed wire with border guards - and facing sovereign decisions to set up immediate barriers to protect the country from the evil of the large numbers of displaced people.

And how these tragic situations for humanity are not far from the creative environment of artists - as art is a mirror of societies and cultures. Rather, art most of the time adopts the role of predictor of events and presenter of the following, and the research adopts the point of view that calls for the right to migrate anywhere and at any time,

\footnotetext{
* Corresponding author: finea-dean@alexu.edu.eg
} 
but with conditions: As stated on In the words of the writer Abdul Hamid Barto, "I consider that the right to live anywhere in this world is a legitimate human choice, and no one has the right to interfere in it, except through a contract, such as if the person is related to another person (the family), or someone decided to participate in Public life for a new place to be a contributor to building a new national situation.

Likewise ... and I still see immigration from the homeland as a threat in the context of brain drain, because it harms the future of the country and future generations, without the slightest disregard for the ambiguous circumstances, but at the highest levels of understanding and appreciation for the need to emigrate, this of course is in addition to solidarity, which It has no limits, as well as recognizing the right of everyone to decide where to live.

Humanity tends to follow a path that is getting more injustice and darkness. The emergence of environmental disasters, famines, forest fires, a torrent of deadly plastic invading land and sea, and pollution is a result of our actions.

We are the ones we attributed with our ambitions to colonize and dispossess other countries from the perspective of the eligibility of the highest and the most pious in sex, education, and civilization for those who are inferior according to the order of the strongest.

We are the ones who colonized the weak countries and destroyed them by harnessing all their resources for us - we are the strong human beings - we are the ones who squandered the dignity of the usurped colonial country and deluded them that they are the lowest, that we are the highest, and that we are the example that must be emulated. That is why he called, "Camo that if there is to be colonialism, respect must be done." The colonized peoples and not distorting them with the cause of their colonists, and the talk here is definitely about the people of Algeria, the one with a million martyrs in their defense against Italian colonialism on the land.

Then there were great wars among the powerful states in which millions of innocent lives were lost with no income - wars over the possession of a spot or the disagreement over the right to power over strength.

Art and global events: It seems that the artists 'destiny in their lives is to express in their works the events of their era - the events of the turbulent and fraught era - or the era that is close to the explosion or the conflict in it raged due to the incompatibility of ideologies and ambitions of possession (colonialism) so the level conflict is wars - and therefore it was not Coincidentally, two artists expressed specific situations at the time of their occurrence - indeed, the contemporary event has elevated their work to the ranks of humanity and immortalized in human history. 


\section{And from global political works:}

In dissecting the relationship between art and politics in the use of art for political propaganda, political propaganda means here that conscious, deliberate and intentional attempt to pass an artistic message through art.

We present here examples of the artists' relationship with the political situations in the world: the artwork "Guernica" which was completed by the artist Picasso in 1937, the year in which the village of Guernica was struck by bombs by Italian and Spanish forces during the Spanish Civil War.

The other work is "The Massacre in Korea" by Picasso also, which he produced in January 1951 - the artist's reaction to the killing of civilians by America and South Korean forces from October to December 1950, with a total death toll estimated at 35,000 people, and from Egyptian political works: Painting "The popular choir" was shown by Al-Jazzar in 1949 in the exhibition of the contemporary serf group. He put himself for her a title "Your subjects, my lord", the satirical title angered King Farouk, the painting was raised and the butcher and his teacher Hussein Yusef Amin were arrested for a short period, and the scene seems bewildering. So that the politician understands it, as if it were a question about this threatened existence, about existence itself, where there is no room for talking about life and its form, but only about the right to remain.

\section{Societal political art:}

An artistic name that appeared in the early nineties, based on not separating art from politics, but on the contrary, political matters became a new platform from which coalitions and gatherings advocating for rights and advocacy for the environment emerged, and politics was considered as a new platform in which artists take a pure documentary but is influenced by events and opinions that surround the world in general and countries in particular .

From the standpoint of political changes in the countries, a large movement emerged to seek refuge in Western lands, or the emergence of cases of illegal immigration in the hope of a better life, but these movements were silent with some inhuman and internationally criminal phenomena, namely human trafficking. The idea of slavery is brought back again after its end in the century The past - is a rewriting of history, internationalization of human evils, a revival of racism, and an expectation of new civil wars, "while socially involved art has continued to develop more intensively since the early 1990s. And here, creative activity in particular has become in recent years the beloved theme of the art world, along with themes. Countless political and economic crises Wherever we are, artists are always the first to participate. 
The works of some contemporary artists on the issue of illegal immigration:

This is what Tania Brugira - activist and performer - believes in: "She believes in how important it is to give art tools to people - as art makes us free - and helps us imagine the future differently.

This artist founded a foundation to support immigrants and named the International Movement for Migration in New York - the International Movement for Migration ...

2010 - IMI-Immigrant Movement International.

IMI operates as a community space where art and education are used to empower immigrants personally and politically. By engaging with contemporary art, Tania Bruguera says, "immigrants understand how to act about their fear and the restrictions they put on themselves once they enter this country."

Her foundation's job is to establish a communicative space where art and education are used. The IML functions as a community space where art and education are used to empower immigrants personally and politically. By dealing with contemporary art, Progera says, "immigrants understand how to act on their fear and the restrictions they place on themselves once entering this country."

Which of the provisions of the movement's manifesto is: "We believe that the only law worthy of respect is that which is far from discrimination or classification.

A law that protects everyone everywhere without exception. We strongly condemn the criminalization of immigrant lives. Human dignity

Have no nationality or race. We demand respect for all immigrants' cultural, social, technical, and political beliefs.

We witnessed and touched the extent of what fear creates barriers, and the extent of hatred that these barriers create, hatred is the ideal servant of oppression and tyranny.

We also understand that both immigrants and non-immigrants are communicating and intersecting. When the rights of the immigrant are denied or violated, the rights of the citizen are in danger.

Tania Brugira was born in Havana in 1968 and received her academic education in 1992 at the Higher School of Art, Havana.

She completed her MA in Performing Arts - Performance - at the Art Institute of Chicago in 2001. In her performance, she tries to eliminate the distance between art and life.

Artwork 10. 142, 926:

Work by artist Projera: "The work is full of thoughts and feelings, starting with its numbered title 
10. 142,926 . Which refers to the number of people who immigrated from one country to another in the year 2017 in addition to the number of deaths among immigrants registered for the year 2018, ending by the method of implementing the same performance.

This work carries a broad meaning for the concept of working in a team, and insists on the right to delay and support. The floor of the hall was painted with a specific coating that reflects the energy of the bodies, and some museum visitors volunteered to agree with them on the date of the performance, and their energies joined forces by approaching all their situations on the floor of the museum hall in a circular shape indicating the continuity of their interdependence with life .. What was mentioned in the manifesto of the international migrant movement: "As we understand Both immigrants and non-immigrants are interconnected and intersect, and when the rights of the immigrant are denied or violated, the rights of the citizen are in danger because it is the realization of the collective performance in this work.

This circle of people of various shapes and cultures has converged, united, and left their impression on the ground traces of their presence together. And at times, they line up in rows.

\section{International artist: Ai Weiwei:}

Ai Weiwei is one of China's most prominent contemporary artists, "who has been able to forge an art movement related to global political activism associated with the contemporary art movement. In his work, he has drawn attention to human rights violations on a global scale, and has expanded the concept of art to include societal engagements. He is an artist who made his life. Really at stake in defense of freedom of expression.

Ai Weiwei says: The artist's job is to provoke ideas, evoke beauty, and find ways to act on the subject at hand. Provocation is always associated with discovery, it is associated with the creation of a new language and skill, but not every provocation of ideas is linked to success. The provocation of ideas succeeds only if he has a deep knowledge of what has happened before, in art, culture, or human life.

Among the works of artist Ai Weiwei: the work presented at the Sydney Biennial "Law of the Journey" - a 60-meter-long vacuum installation of a rubber boat with hundreds of unidentified immigrants - about 312 models of them.

The work reflects the artist's focus in recent years on defending human rights, refugees and migrants, documenting the experiences and conditions faced by hundreds of people who have been forcibly displaced from their homes. The artist says: There is no two-refugee crisis, but a humanitarian crisis .. We need more tolerance, compassion and trust for each other, because we are all one, otherwise humanity will face a greater crisis. 


\section{Results :}

The research concludes from the above:

1- That the two types of immigration occur naturally and officially through identification papers, or it occurs illegally as long as the individual is no longer safe for himself or his family for various reasons, economically - politically - environmentally.

2- In illegal immigration there are dangers and evils - where illegal immigrants meet the horrors of travel and risk their lives in boats of death and not deliverance, hoping for a better life for them and their families - that the instinct for stronger survival is a weapon known to man and by which he adjusts his stability to travel if necessary in order to reach happiness - as he thinks. Despite the relentlessness of states and governments in assisting migrants and refugees, human rights organizations and humanitarian institutions such as doctors without borders, in addition to ships specially working to rescue the flooded from the horrors of the Mediterranean Sea, give hope for humanity - far from state policies. The exacerbation of the phenomenon of illegal immigration is what made some countries strive to find solutions, such as the European Commission and the Marrakesh Migration Conference.

3- We also conclude that contemporary art is able to express the phenomenon and to raise the alarm bell for humanity, and to be supportive of united energies and a sense of the other - as we have seen in the works of Tania Progera and Ai Weiwei.

\section{Recommendations:}

The research recommends two recommendations based on:

1- The International Movement for Migration Manifesto, founded by the artist Tania Brugira, and from the sayings of the artist Ai Weiwei:

- From the movement's manifesto: "We believe that the only law worthy of respect is that which is far from discrimination or classification.

A law that protects everyone, everywhere, without exception.

We strongly condemn the criminalization of immigrant lives. Human dignity has no nationality or race. We demand respect for all immigrants' cultural, social, technical, and political beliefs. We have witnessed and touched the extent of what fear creates barriers, and the extent of hatred that these barriers create, hatred is the ideal servant of oppression and tyranny. We also understand that both immigrants and non-immigrants are communicating and intersecting. When the rights of the immigrant are denied or violated, the rights of the citizen are in danger. From the sayings of the artist, Ai Weiwei:

"There is no refugee crisis, but a humanitarian crisis .. We need more tolerance, compassion and trust for each other, because we are all one, otherwise humanity will face a greater crisis." 


\section{References}

1- Abdel Hamid Birto - The number of displaced people and refugees is greater than what we expect - Al-Hiwar Civilized - An electronic newspaper. Accessed March 11, 2019.

http://www.ahewar.org/debat/show.art.asp?aid=457307

2- Naked Life - Adel Al-Siwi - "Madina electronic newspaper, accessed on February 10, 2019 https://www.medinaportal.com/series/\%D8\%AD\%D9\%8A\%D8\%A7\%D8\%A9\%D8\%B9\%D 8\%A7\%D8\%B1\%D9\%8A\%D8\%A9/

3- "Cami and Sartre", The World of Knowledge Series, Issue 334, December 2006.

4- Aquarius, a migrant rescue ship in the Mediterranean - Al-Muhajir News - electronic newspaper accessed on 10 March 2019 -

https://www.info/igrants.net/ar/post/2969/\%D8\%A3\%D9\%83\%D9\%88\% D8\% A7\% D8\%

B1\% D9\% 8A\% D9\% 88\% D8\% B3\% D8\% B3\% D9\% 81\% D9\% 8A\% D9\% 86\% D8\% A9\% $\mathrm{D} 8 \% \mathrm{~A} 5 \% \mathrm{D} 9 \%$ 86\% D9\% 82\% D8\% A7\% D8\% B0\%

D8\% A7\% D9\% 84\% D9\% 85\% D9\% 87\% D8\% A7\% D8\% AC\% D8\% B1\% D9\% 8A\% D9\% 86\% D9\% 85\% D9\% 86\% D8\% A7\% D9\% 84\% D8\% BA\% D8\% B1\% D9\% 83\%

D8\% A8\% D8\% A7\% D9\% 84\% D9\% 85\% D8\% AA\% D9\% 88\% D8\% B3\% D8\% B7,

5- The Massacre in Korea - 2 Accessed March 2019

https://www.pablo-ruiz-picasso.net/work-4020.php

6- Clandestine immigration and missing human security - Muhammad Al-Bakuri - Al-Hiwar Al-Muhtamdan Newspaper Accessed on 12 March 2019 Issue 4784

http://www.ahewar.org/debat/show.art.asp?aid=464825

7- What are the most important contents of the global compact for migration aggressed in Marrakech? France 24 Live Broadcast - Accessed on March 10, 2019

https://www.france24.com/ar/20181210-

$\%$ D8\% AD\% D9\% 82\% D9\% 88\% D9\% 82

\% D8\% A7\% D9\% 84\% D8\% A5\% D9\% 86\% D8\% B3\% D8\% A7\% D9\% 86

\% D9\% 85\% D9\% 8A\% D8\% AB\% D8\% A7\% D9\% 82

\% D8\% A7\% D9\% 84\% D9\% 87\% D8\% AC\% D8\% B1\% D8\% A9

\% D8\% A7\% D9\% 84\% D8\% A3\% D9\% 85\% D9\% 85

\% D8\% A7\% D9\% 84\% D9\% 85\% D8\% AA\% D8\% AD\% D8\% AF\% D8\% A9

\% D9\% 85\% D8\% A4\% D8\% AA\% D9\% 85\% D8\% B1

\% D9\% 85\% D8\% B1\% D8\% A7\% D9\% 83\% D8\% B4

8- Decrease politics: How does art create globalized political movements? Dina Hassan March 12, 2019 
https: // elbadilpss, org / 2017 / 08/09 /\% D8\% AA\% D9\% 81\% D9\% 86\% D9\% 8A\% D9\% 86\% D8\% A7\% D9\% 84\% D8\% B3\% D9\% 8A \% D8\% A7\% D8\% B3\% D8\% A9

\% D9\% 83\% D9\% 8A\% D9\% 81-\% D9\% 8A\% D8\% AE\% D9\% 84\% D9\% 82

\% D8\% A7\% D9\% 84\% D9\% 81\% D9\% 86

\% $\mathrm{D} 8 \% \mathrm{AD} \% \mathrm{D} 8 \% \mathrm{~B} 1 \% \mathrm{D} 9 \%$ 83\% D8\% A7\% D8\% AA

$\% \mathrm{D} 8 \% \mathrm{~B} 3 \% \mathrm{D} 9 \%$ 8A\% D8\% A7\% D8\% B3

9- Tania Brugira - The International Movement of Migrants, ART 21 - accessed on February 17, 2019.

https://art21.org/watch/extended-play/tania-bruguera-immigrant-movement internationalshort /

10- Manifesto of the International Migration Movement - accessed on February 17, 2019 http://immigrant-movement.us/wordpress/migrant-manifesto/

11- The Freeze Newspaper - Immigration and Neighborhood in the work of Tatia Progera accessed on February 26, 2019

https://frieze.com/article/migration-and-neighbourliness-tania-brugueras-turbine-

hallcommission

12- Artist Drowned in the Land of Refugees - India Today - Online newspaper accessed on 17 March 2019

Artist Awash in the land of refugees- India Today.

https://www.indiatoday.in/magazine/special-report/story/20160215-ai-weiwei-tributeto syrian-refug00-aylan-kurdi-828413-2016-02-03

13- Ai Weiwei - Contemporary Chinese Artist - accessed on February 21, 2019.

https://www.theartstory.org/artist-ai-weiwei.htm

14- The official Sydney Biennial page - Ai Weiwei - accessed on 17 March 2019.

https://www.biennaleofsydney.art/artists/ai-weiwei/

15- What role can art play in politics? Accessed February 11, 2019.

https://www.goethe.de/ins/b/en/kul/mag/20559574.html

16- Lina Emad FATHY, THE ELOQUENCE OF THE PHOTOGRAPHIC IMAGE IN THE DESIGNS OF POSTERS OF HUMANITARIAN ORGANIZATIONS (POSTERS OF DISPLACED IRAQIS AS A MODEL), International Journal of Humanities and Language Research, Vol. 2, No. 2, 2019, pp. 26-32. 